\title{
Velhos e novos desafios ao direito e à justiça
}

Boaventura de Sousa Santos, Conceição Gomes e Madalena Duarte

\section{OpenEdition}

\section{Journals}

Edição electrónica

URL: http://journals.openedition.org/rccs/1425

DOI: $10.4000 /$ rccs. 1425

ISSN: 2182-7435

Editora

Centro de Estudos Sociais da Universidade de Coimbra

Edição impressa

Data de publição: 1 Dezembro 2009

Paginação: 5-8

ISSN: 0254-1106

\section{Refêrencia eletrónica}

Boaventura de Sousa Santos, Conceição Gomes e Madalena Duarte, «Velhos e novos desafios ao direito e à justiça », Revista Crítica de Ciências Sociais [Online], 87 | 2009, colocado online no dia 15 outubro 2012, criado a 04 maio 2019. URL : http://journals.openedition.org/rccs/1425 ; DOI : $10.4000 /$ rccs. 1425

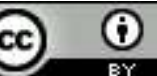




\section{Velhos e novos desafios ao direito e à justiça}

O direito tem sido crucial não só pelo seu papel instrumental na gestão de conflitos sociais, mas sobretudo na reprodução social do paradigma da modernidade. Esta concepção moderna do direito tem-se fundamentado na construção científica de um direito monopolizado pelo Estado, na despolitização de um direito que oculta a existência de relações de poder para além da relação entre Estado e sociedade civil e no uso do direito enquanto instrumento universal da transformação social politicamente legitimada. A incapacidade do Estado para traduzir as promessas da modernidade de igualdade, liberdade e paz em direitos fundamentais efectivos revela que a crise desse modelo de regulação exige um repensar do papel do direito e da justiça nas sociedades contemporâneas.

Este número da Revista Crítica de Ciências Sociais reúne um conjunto de reflexões sobre a área do(s) direito(s) e da justiça. Pretendemos, através delas, dar conta de alguns desafios que se colocam actualmente ao direito, alguns recentes, outros mais antigos, mas todos igualmente prementes. À sociologia do direito cabe estar atenta a estas transformações sociais e ao impacto que têm, ou poderiam ter, no direito. É certo que não podemos afirmar com certeza por que rumo seguirá a sociologia do direito no futuro, mas, guiados pela sociologia das emergências, podemos dar conta de pistas, sinais, ou de, nas palavras de Ernst Bloch, "ainda nãos".

Um primeiro desafio consiste na construção de uma jurisprudência que transcenda o Estado e caminhe para o que se designa por transnacionalismo jurídico. Somos desafiados a repolitizar o direito, superando a concepção deste como direito do Estado e da política como política estatal, o que implica pensar na capacidade transformadora do direito para além do que é politicamente legitimado pelo Estado. A teoria sociojurídica deve, pois, ter presente diferentes escalas de aç̧ão, bem como atender a redes comunitárias diversas $e$ a poderes e autoridades concorrentes. O texto de Paula Meneses é a este respeito esclarecedor. O artigo procura debater os desafios que Moçambique enfrenta na construção de um sistema de justiça multicultural e democrático. As experiências de justiças comunitárias descritas no texto revelam a criatividade e a vitalidade das outras justiças e a sua decisão em defender a 'sua' justiça como projecto político. Ao mesmo tempo, a diversidade de instâncias 
indicia as disputas e jogos de poder face a um Estado que reconbece, até certa medida, a presença de outras jurisdições, constituindo um complexo jogo de interlegalidades.

Vemos assim que, se até recentemente a sociologia do direito contemporânea encarava o direito meramente como um instrumento estatal, hoje as próprias complexidades regulatórias dos diferentes Estados não permitem a perpetuação de um foco tão restrito de análise. Cecília M. Santos, Ana C. Santos, Madalena Duarte e Teresa M. Lima demonstram bem isso no seu texto, ao examinarem a mobilização judicial em torno do reconbecimento do direito à bomoparentalidade e a reconstrução dos direitos bumanos à luz do caso Silva Mouta, iniciado nos tribunais portugueses e encaminhado posteriormente ao Tribunal Europeu de Direitos Humanos. O artigo reflecte tensões e disjunções entre diferentes escalas da justiça estatal e inter-estatal, por um lado, e entre o direito e a sociedade, por outro, num caso que trouxe para o campo judicial desafios sociais e jurídico-políticos decorrentes de reivindicações de minorias sexuais num contexto predominantemente conservador.

Podemos afirmar, na sequência do raciocínio anterior, que a discussão sobre o potencial emancipatório do direito exige uma sociologia crítica que não se limite a eliminar por completo a ideia de transformação social através do direito, na esteira dos Critical Legal Studies, e que possa investigar as práticas de grupos e classes socialmente oprimidas que lutam contra a opressão, a exclusão, a discriminação e a destruição do meio ambiente, recorrendo ao direito ou a diferentes formas de direito, dentro ou fora dos limites do direito oficial moderno, mobilizando diversas escalas de legalidade (locais, nacionais e globais) e construindo alianças translocais e até transnacionais. Nesta perspectiva, a construção de uma sociologia crítica do direito é também desenvolvida e reforçada pela perspectiva feminista, influenciando teórica e empiricamente todo esse campo de estudos. O texto de Boaventura de Sousa Santos, Conceição Gomes e Madalena Duarte parte precisamente desta perspectiva. Analisando as experiencias e subjectividades das mulheres traficadas, os/as autores/as debruçam-se sobre algumas das questões emergentes $e$ ausentes no enquadramento legal do tráfico sexual de mulheres, recorrendo à realidade empírica do tráfico sexual em Portugal. O artigo evidencia que a definição legal de "consentimento", bem como a construção legal e social de vítima são, não raras vezes, informadas por estereótipos de género que impõem um certo conservadorismo, prejudicial, sobretudo, para as mulheres vítimas de tráfico sexual.

Ainda no que se refere à simbiose entre política e direito, são apresentados os textos de Jacques Commaille e de Élida Lauris. Como demonstra Comaille, a relação intima e contraditória entre direito e política tem resultado tanto 
na construção de uma regulação jurídica utilitária ao serviço do político como numa regulação política dependente do campo jurídico. As oscilações nesta relação variam de acordo com as orientações sociopolíticas adoptadas pela justiça: racionalização, democratização ou neoliberalização. A adopção de uma perspectiva sociopolítica na abordagem das transformações sofridas pela justiça também orienta o artigo de Élida Lauris. Ao centrar-se no tema do acesso ao direito, um desafio antigo e constante que tem tanto de urgente como de indispensável para se atingir a justiça, explora as combinações possiveis na configuração política do acesso à justiça nas sociedades contemporâneas. Com este objectivo, e recorrendo ao caso concreto da consolidação do sistema de assistência jurídica em São Paulo, analisa as lutas sociais e os confrontos políticos que subjazem à decisão da política pública de acesso à justiça na actualidade, demonstrando a permanente dualidade entre os propósitos de universalização do acesso e as estratégias de racionalização dos serviços jurídicos. Este texto evidencia, ainda, a problemática do acesso à justiça para defesa de bens colectivos, desafiando a lógica individualista tradicional do direito.

Como referimos inicialmente, há desafios outros que emergem e se colocam às sociedades e ao direito. Um deles é novo pelo conteúdo, ainda que não pela forma: falamos da relação da ciência com o direito. O aparecimento do positivismo na epistemologia da ciência moderna e do positivismo juridico no direito e na dogmática jurídica podem considerar-se, em ambos os casos, construções ideológicas destinadas a reduzir o progresso societal ao desenvolvimento capitalista. Hoje, no entanto, a ciência e o direito podem fundir-se em outras energias. Há novas matérias que apontam para os novos e fascinantes territórios do jurídico, espaços onde os institutos jurídicos tradicionais e as clássicas distinções disciplinares são definitivamente colocados à prova. Isto numa altura em que, de forma crescente, se questionam os limites ético-jurídicos da ciência e da técnica e se levantam dilemas preocupantes a propósito dos fenómenos epidémicos à escala global. Destas novas matérias nos dão conta os artigos de João Arriscado Nunes e de Susana Costa. O primeiro propõe uma abordagem preliminar dos processos heterogéneos e contingentes através dos quais se definem e constituem mutuamente a saúde e o direito à saúde. São apresentadas e discutidas duas manifestações recentes dessa dinâmica: o direito à saúde como imperativo, centrado na responsabilização individual e na centralidade da vigilância e da prevenção; e a designada justiça sanitária, exemplificada através de situações em que cidadãos procuram o reconbecimento como portadores de uma doença, os direitos associados a essa condição e a aç̧ão pública sobre situações que afectam a sua saúde. O segundo tenta mostrar de que forma é que o desajustamento entre o edifício legal e o edifício da ciência no quadro das 
Averiguações Oficiosas de Paternidade pode levar à emergência da redefinição do direito e de uma reflexão alargada sobre a forma como a prova é incorporada na decisão judicial.

Nestas diversas tendências emergentes e consolidadas, há dois aspectos que se salientam e que procuramos demonstrar nas reflexões incluídas nos diversos textos. O primeiro é que nas novas tendências que se consolidam na sociologia do direito a perspectiva privilegiada é aquela que parte do Sul Global. Se queremos encontrar respostas, alternativas para os diversos desafios com que nos vamos confrontando, então devemos superar a tradição crítica ocidental.

A segunda é a de que não devemos confundir objectividade com neutralidade. Quando estamos inseridos em sociedades com oprimidos e opressores, onde há um fosso crescente entre ricos e pobres e onde a violência conhece múltiplas formas, temos de decidir em que lado nos posicionamos. É o que pretendemos com este número da revista: dar um contributo para colocar a justiça ao serviço da cidadania e do aprofundamento da democracia.

Boaventura de Sousa Santos

Conceição Gomes

Madalena Duarte 